\title{
EKSISTENSI PENGADILAN AGAMA PASCA PENYATUAN SATU ATAP (INDEPENDENSI DAN PENGEMBANGANNYA)
}

\author{
Mardi Candra
}

Hakim pada Pengadilan Agama Kabupaten Malang, Indonesia

\begin{abstract}
Abstrak: Pengadilan Agama merupakan representasi penerapan hukum Islam di Indonesia. Penyatuan satu atap Pengadilan Agama di bawah Mahkamah Agung merupakan sebuah sejarah penting dalam dinamika perkembangan Pengadilan Agama. Tujuan penelitian ini adalah untuk menelaah eksistensi Pengadilan Agama pasca penyatuan ke dalam Mahkamah Agung. Eksistensi pengadilan agama pasca penyatuan satu atap menjadi lebih baik dan dinamis. Dari segi indenpensi, komitmen Mahkamah Agung dalam menjaga indenpendensi lembaga peradilan dan menjauhkan Pengadilan Agaman dari anomali black justice market atau judicial corruption. Sedangkan dari segi perkembangann, pengadilan agama mengalami kemajuan pesat terutama dalam hal pembangunan infrastruktur, pelayanan publik, penguasaan dan penerapan informasi teknologi, pembangunan sumber daya manusia, dan apresiasi dunia internasional.
\end{abstract}

Kata Kunci: Eksistensi, Pengadilan Agaman, Satu Atap.

\section{PENDAHULUAN}

Sebelum mempresentasikan pokok-pokok pikiran tentang eksistensi Pengadilan Agama pasca penyatuan satu atap, saya ingin menyampaikan rasa hormat kepada Bapak Rektor, Bapak Dekan Fakultas Hukum dan seluruh sivitas akademika Universitas Muhammadiyah Malang, melalui Bapak Kepala Program Studi Program Pascasarjana Universitas Muhammadiyah Malang, Bapak Mokh. Najih, SH., M.Hum., Ph.D yang telah mengundang untuk berbagi pengalaman di seputar indenpendensi dan pengembangan Pengadilan Agama pasca penyatuan satu atap di bawah Mahkamah Agung, yang dikemas dalam acara kuliah umum Program Magister Ilmu Hukum Pascasarjana Muhammadiyah Malang, semoga dapat memberikan manfaat bagi kedua lembaga, baik lembaga peradilan maupun lembaga pendidikan Muhammadiyah di Indonesia.

Pengadilan Agama merupakan representasi penerapan hukum Islam di Indonesia. Pada dasarnya Hukum Islam (Islamic law) merupakan kata lain dari Syariat Islam yang didefinisikan sebagai hukum yang berasal dari wahyu Allah yang diturunkan kepada Nabi
Muhammad saw., untuk mengatur manusia dan alam semesta (Amin, 1985). Menurut Abdullah Ahmed anNa'im, syariah bukanlah Islam itu sendiri, melainkan ia hanyalah interpretasi terhadap nash yang pada dasarnya dipahami dalam konteks historis tertentu (An-Na'im, 1994). Hukum Islam yang terserap dalam hukum positif di Indonesia mengalami pasang surut seiring dengan politik hukum yang diterapkan oleh kekuasaan Negara, termasuk kekuatan sosial budaya yang berinteraksi dalam proses pengambilan keputusan politik. Transformasi hukum Islam ke dalam perundang-undangan nasional merupakan hasil interaksi antara para ulama dengan elite politik atau penguasa. Baik tersurat maupun tersirat, banyak asasasas hukum Islam yang terserap dalam hukum nasional. Suatu kenyataan yang akan memberikan prospek ke depan lebih baik, di mana hukum Islam akan menjadi inspirasi utama dalam pembangunan hukum nasional. Memang bagaimanapun juga masalah agama (Islam), politik, dan negara selalu terkait satu sama lainnya. Menurut KH. Wahab (Rois Akbar NU), bahwa dalam kalimat Islam terkandung soal-soal politik dan Hukum Tata Negara. Kalau orang bisa memisahkan antara gula dengan manisnya, maka dapatlah ia memisahkan 
agama Islam dengan politik (Ahmad, 2001). Namun demikian, hukum Islam telah mengalami perkembangan secara berkesinambungan, baik melalui jalur infrastruktur politik maupun suprastruktur politik dengan dukungan kekuatan sosial budaya. Penyerapan hukum Islam tanpa dukungan politik sulit digali dan diterapkan. Politik yang mengabaikan hukum Islam akan mengakibatkan kekacauan dalam masyarakat. Oleh karena itu, semakin baik hubungan Islam dan politik semakin besar peluang hukum Islam diaktualisasikan, dan semakin renggang hubungan Islam dan politik, semakin kecil peluang hukum Islam diterapkan (Halim, 2000). Cara pandang dan interpretasi yang berbeda dalam keanekaragaman pemahaman orang Islam terhadap hakikat hukum Islam telah berimplikasi dalam sudut aplikasinya. Keanekaragaman yang dimaksud adalah perbedaan pemahaman orang Islam di dalam memahami hukum Islam yang memiliki dua kecenderungan, yakni hukum Islam identik dengan syari'ah dan identik dengan fiqh. Ini banyak terjadi bukan hanya di kalangan ulama Fiqh, tetapi juga di kalangan akademisi dan praktisi hukum Islam. Beberapa hal yang ikut berkonstribusi dalam memperkaya bidang pemikiran hukum Islam, dapat dibagi menjadi empat jenis, yakni kitab-kitab fiqh, putusan-putusan Pengadilan Agama, peraturan Perundang-undangan di negeri-negeri muslim dan fatwa-fatwa ulama. Keempat faktor tersebut diyakini memberi pengaruh cukup besar dalam proses transformasi hukum Islam di Indonesia, terutama dalam indenpendensi dan pengembangan Pengadilan Agama pasca one roof system di bawah Mahkamah Agung.

Penyatuan satu atap Pengadilan Agama di bawah Mahkamah Agung merupakan sebuah sejarah penting dalam dinamika perkembangan Pengadilan Agama. Pada dasarnya sejak masa pra kolonial Belanda, syariat Islam merupakan satu-satunya sistem hukum yang dijalankan dan menjadi kesadaran hukum yang berkembang dalam sebagian besar masyarakat hukum adat di Indonesia (Harjono, 1968). Diawal masa kolonial, kondisi tersebut kemudian mendorong lahirnya Statblaad 1882 nomor 152 sebagai legislasi berdirinya Pengadilan Agama di Jawa dan Madura. Kemudian terjadi perubahan politik hukum Kolonial
Belanda, yang dipelopori oleh Christian Snouck Hurgronje (1857-1936) yang sangat menyesalkan diakuinya Pengadilan Agama di Indonesia oleh pemerintah Kolonial Belanda (Hasan \& Sumitro, 1994). Selanjutnya secara berangsur-angsur politik hukum Belanda mengganti keberadaan hukum Islam dengan hukum kolonial. Oleh karena itu hukum Indonesia pasca kolonial pada umumnya adalah warisan kolonial Belanda tersebut. Kemudian pada waktu Indonesia memproklamirkan kemerdekaan memang terjadi peralihan kekuaasaan dari penjajah ke orang Indonesia, tetapi tidak terjadi peralihan dari hukum Belanda ke hukum Indonesia secara sistematis, kecuali Undang-undang Dasar 1945 sebagai produk Indonesia yang disusun secara darurat. Semua hukum yang berlaku setelah pengesahan Undang-undang Dasar 1945 pada tanggal 18 Agustus 1945, baik hukum perdata, hukum pidana maupun hukum acara, ataupun hukum lainnya, adalah kelanjutan dari hukum yang belaku di wilayah administrative Belanda. Setelah mulai stabil, Indonesia juga memperkenalkan hukum Indonesia sendiri, tetapi sesungguhnya wawasan perancang dan pembuat hukum di Indonesia belum dapat melepaskan diri wawasan hukum asing. Dalam konteks ini, menurut Prof. Mr. Rosalan Saleh (guru besar hukum pada Fakultas Hukum Universitas Indonesia Salemba) yang diwawancarai pada bulan Januari 1996, pernah menyatakan bahwa penyusunan Kitab-kitab Hukum di Indonesia sering meminta pertimbangan kepada ahli hukum asing atau bahkan ke Mahkamah Agung Belanda (Ka’bah, 2002).

\section{METODE PENELITIAN}

Dalam penelitan ini digunakan penelitian hukum normatif, yaitu penelitian yang dilakukan terhadap asas-asas hukum, kaedah-kaedah hukum dalam arti nilai (norm), peraturan hukum konkrit dan sistem hukum (Mertokusumo, 2004), yang berhubungan dengan materi yang diteliti berkaitan dengan eksistensi pengadilan agama pasca penyatuan satu atap.

Selanjutnya pendekatan masalah yang digunakan yaitu: pertama, Pendekatan Perundang-Undangan (statute approach); kedua, Pendekatan Konseptual (conceptual approach); ketiga, dan ketiga, Pendekatan Perbandingan (Ibrahim, 2010). 
Cara atau teknis pengumpulan bahan hukum yang digunakan adalah studi dokumentasi yakni dengan mencatat informasi dari bahan hukum yang berkaitan dengan eksistensi pengadilan agama pasca penyatuan satu atap. Pencatatan ini dilakukan secara selektif untuk mendukung dan melengkapi bahan hukum yang diperoleh dari sumber lain

\section{PEMBAHASAN}

\section{A. Indenpendensi Pengadilan Agama Pasca}

\section{Penyatuan Satu Atap}

Kekuasaan kehakiman pada Peradilan Agama dilakukan oleh pengadilan Agama yang terdiri atas Pengadilan Agama sebagai peradilan tingkat pertama dan Pengadilan Tinggi Agama sebagai badan peradilan tingkat banding. Pengadilan Agama mempunyai daerah hukum yang sama dengan Pengadilan Negeri. Menurut Roihan A Rasyid, Peradilan Agama telah ada diberbagai tempat di Indonesia sejak abad ke-16. Dalam sejarah, tanggal 19 Januari 1882 ditetapkan sebagai hari jadinya, yaitu berbarengan dengan diundangkannya ordonantie Stbl. 1882-152 tentang Peradilan Agama di Pulau Jawa dan Madura (Rasyid, 2000). Peradilan Agama merupakan salah satu pelaksana kekuasaan kehakiman bagi rakyat pencari keadilan yang beragama Islam, mengenai perkara perdata tertentu yang diatur dalam undang-undang (Arto, 2003). Pengadilan Agama dibentuk dengan Keputusan Presiden. Pengadilan Tinggi Agama dibentuk dengan undang-undang, sedangkan Mahkamah Agung dibentuk berdasarkan Pasal 24 UUD 1945 (Mujahidin, 2008).

Peradilan agama, secara de jure, mulai bergabung dengan Mahkamah Agung pada tahun 2004, sebagai tindak lanjut ketentuan Pasal 42 ayat (2) UndangUndang Nomor 4 Tahun 2004 tentang Kekuasaan Kehakiman. Pada dasarnya politik satu atap tersebut telah dimulai sejak UU No. 35 Tahun 1999 tentang Perubahan terhadap UU No. 14 Tahun 1970 Tentang Pokok-Pokok Kekuasaan Kehakiman. Di Mahkamah Agung, peradilan agama jadi satu atap bersama peradilan umum, peradilan militer dan peradilan tata usaha negara. Indenpendensi Pengadilan Agama pasca penyatuan satu atap tetap terjaga, bahkan bisa dikatakan terlaksana lebih baik dari sebelumnya. Hal ini terwujud karena komitmen Mahkamah Agung dalam menjaga indenpendensi lembaga peradilan. Tujuanya adalah untuk menjaga peradilan agar tidak terkena pengaruh atau dengan kata lain untuk menghindari adanya turut campur dua kekuasaan lain; legislatif dan eksekutif.

Sejak masih berada di bawah Kementerian Agama hingga kemudian hijrah ke Mahkamah Agung, peradilan agama jadi semacam anomali terhadap fenomena black justice market atau judicial corruption. Berbagai riset membuktikan hal itu. Dalam hasil riset bertajuk Survey Report on Citizen Perceptions of The Indonesian Justice Sector yang diterbitkan The Asia Foundation bekerjasama dengan AC Nielson pada tahun 2001, disebutkan bahwa kinerja peradilan agama menduduki peringkat tertinggi (the highest performance), terpercaya (trustworthy), melaksanakan tugas dengan baik (does job well), tepat waktu (timely), sangat membantu (helpful), dan menjadi tempat pertama ketika menghadapi masalah hukum (the first to go with a legal problem). Berdasarkan kelima kualitas yang dijadikan sebagai ukuran kinerja tersebut, The Asia Foundation dan AC Nielson menyimpulkan peradilan agama masuk dalam kriteria efektif.

Berselang lima tahun, IALDF (Indonesia Australia Legal Development Facilities) bekerjasama dengan PPM UIN Jakarta merilis sebuah laporan penelitian berjudul Providing Justice for Justice Seeker: A Report on the Indonesian Religious Court Access and Equity 2007. Penelitian itu berhasil memotret bagaimana masyarakat menilai kualitas pelayanan hukum di peradilan agama. Ternyata, dalam pandangan masyarakat yang disurvei, Peradilan Agama telah mempermudah masyarakat mengakses keadilan. Penelitian yang dibiayai oleh Ausaid itu dilakukan secara berkelanjutan selama tiga tahun hingga 2009. Hasilnya kemudian dituangkan dalam buku berjudul Memberi Keadilan bagi Para Pencari Keadilan: Sebuah Laporan tentang Akses dan Kesetaraan pada Pengadilan Negeri dan Pengadilan Agama di Indonesia Tahun 2007-2009.

Selama kurun waktu tersebut, peradilan agama menunjukkan kinerja pelayanan yang konsisten. Dua laporan tersebut selanjutnya dijadikan sebagai titik awal untuk mengembangkan program-program akses terhadap keadilan, khususnya terhadap kaum miskin, 
perempuan dan mereka yang tinggal di wilayah yang sulit dijangkau oleh pengadilan. Tiga program utama lahir setelah itu, yakni pembebasan biaya berperkara bagi kaum miskin, sidang keliling (circuit court) dan pos bantuan hukum. Ketiga program tersebut dijalankan dengan baik oleh pengadilan-pengadilan di lingkungan peradilan agama. Keberhasilan program program tersebut menarik perhatian berbagai pihak.

Pelbagai apresiasi pun diterima peradilan agama. Sebutlah apresiasi yang diberikan oleh Cate Sumner, aktivis peradilan dan HAM berkebangsaan Australia dan Prof. Timothy Lindsay, guru besar Asian Law dari Melbourne University, Australia. Keduanya menulis buku berjudul Courting Reform: Indonesia's Islamic Courts and Justice for the Poor. Buku tersebut mengulas kesuksesan pengadilan-pengadilan di lingkungan peradilan agama dalam empat hal sekaligus. Pertama, pengembangan akses yang lebih baik terhadap pengadilan bagi kaum perempuan. Kedua, peningkatan jumlah layanan prodeo atau pembebasan biaya perkara yang memungkinkan masyarakat miskin menyelesaikan permasalahannya. Ketiga, peningkatan jumlah sidang keliling yang memungkinkan masyarakat yang jauh dari pengadilan dapat mengakses layanan pengadilan. Dan keempat, pengembangan sistem teknologi informasi yang bertujuan meningkatkan akuntabilitas dan transparansi pengadilan.

Program-program tersebut, menurut Cate Sumner dan Tim Lindsay, telah berhasil memposisikan Peradilan Agama sebagai agen perubahan dalam mengembangkan akses yang lebih baik terhadap pengadilan dan mendukung program pengentasan kemiskinan yang tengah digalakkan oleh pemerintah. Atas dasar itu, kedua peneliti tersebut menjadikan pengadilan-pengadilan di lingkungan Peradilan Agama sebagai model pengadilan, tidak hanya bagi pengadilan pengadilan di lingkungan peradilan lainnya di Indonesia, tetapi juga model peradilan Islam di Asia Tenggara.

Selain itu, terdapat apresiasi yang ditunjukkan oleh UNODC (United Nations Office on Drug and Crime). Lembaga yang bernaung di bawah PBB yang bermarkas di Wina Austria tersebut menjadikan keberhasilan peradilan agama dalam pelayanan hukum sebagai contoh terbaik (best practice) bagaimana pengadilan memberikan pelayanan kepada pencari keadilan. Atas prakarsa UNODC, pada 13 Maret 2014 lalu, keberhasilan peradilan agama itu dikuatkan dalam sebuah lokakarya di Teheran, Iran. Ini berarti di bidang pelayanan, pengadilan-pengadilan di lingkungan agama sudah menjadi model bagi pengadilan di dunia.

Keberhasilan Peradilan Agama juga menarik perhatian kalangan akademisi internasional yang memberikan perhatian terhadap penegakan hukum di Indonesia. Salah satunya Prof. Mark Cammack, Guru Besar dari Southwestern Law School Los Angeles, USA. Dalam buku Islamic Law in Contemporary Indonesia: Ideas and Institutions (2007), Prof. Cammack menyebut meski masih ada beberapa kelemahan, peradilan agama relatif merupakan kisah sukses dalam sistem hukum yang disfungsi (disfunctional legal system) di Indonesia. Kondisi disfungsi itu, menurut Prof. Cammack, berarti kondisi yang abnormal atau buruk dalam pelaksanaan sebuah lembaga atau sistem. Prof. Cammack mempertegas pernyataan Prof. Daniel S. Lev. Indonesianis asal Australia yang menulis buku fenomenal berjudul Islamic Court in Indonesia itu terlebih dulu mengakui bahwa Peradilan Agama merupakan pengecualian dari persepsi publik yang kurang baik terhadap lembaga peradilan. Ini karena, menurut Lev, Peradilan Agama bekerja dengan baik.

\section{B. Perkembangan Pengadilan Agama}

\section{a. Perkembangan Infrastruktur Peradilan Agama}

Setelah politik satu atap berjalan efektif, mulai dilakukan pembinaan secara seksama dengan dukungan anggaran pembangunan yang memadai, sehingga pembinaan administrasi, finansial dan organisasi dilakukan (Abdullah, 2008). Salah satu langkah yang dilakukan oleh pimipinan Mahkamah Agung RI, terkait dengan Peradilan Agama, pasca satu atap di bawah Mahkamah Agung RI, adalah meninjau langsung sarana dan prasarana gedung perkantoran pengadilan agama dan pengadilan militer di seluruh Indonesia, serta menyiapkan konsep pembangunan gedung kantor pengadilan agama yang layak dan standar, sehingga sekarang terlihatlah bangunan gedung kantor Pengadilan Agama yang layak dan 
megah, yang sebelum kecil dan sempit dengan tata letak yang tidak layak. Terdapat kalimat yang menarik dari Bagir Manan, saat mobil membawa beliau meninjau kantor Pengadilan Agama, "Kalau saya dibawa melelui jalan sempit, dan berkelok seperti ini, pasti menuju kantor pengadilan agama”. Selain itu, terdapat penambahan yang signifikan kwantitas Pengadilan Agama di Indonesia, ketika masih berada di Kementerian Agama, peradilan agama terdiri dari 327 pengadilan tingkat pertama dan 25 pengadilan tingkat banding. Selanjutnya setelah bergabung di bawah MA, Peradilan Agama terdiri dari 359 pengadilan tingkat pertama dan 29 pengadilan tingkat banding.

\section{b. Perkembangan Pelayanan publik}

Pada tahun 2012 Mahkamah Agung berhasil jadi nomor satu dalam Survei Integritas Sektor Publik untuk kategori instansi vertikal. Pada survei yang diselenggarakan KPK tersebut, Mahkamah Agung diwakili oleh pengadilan-pengadilan dari lingkungan peradilan agama. Dengan skor 7,10, MA unggul atas empat instansi vertikal lainnya yang dijadikan sasaran survei, yaitu Kementerian Hukum dan HAM, Kepolisian RI, Kementerian Agama dan Badan Pertanahan Negara. Ada dua variabel yang digunakan KPK untuk mengukur skor integritas sektor publik. Kedua variabel itu adalah pengalaman integritas dan potensi integritas. Kedua variabel itu dirinci menjadi enam indikator dan 18 sub-indikator. KPK mengadakan Survei Integritas Sektor Publik dalam rangka memberikan penilaian terhadap integritas layanan yang diberikan oleh lembaga publik kepada masyarakat. Hasil penilaian merupakan cerminan bagaimana masyarakat sebagai pengguna layanan memberikan penilaian terhadap layanan lembaga tersebut. Dan ternyata, mewakili MA, pengadilanpengadilan dari lingkungan peradilan agama mendapat skor tertinggi.

Pada tahun 2013, kualitas layanan peradilan agama dan peradilan lain diukur lewat survei. Kali ini yang mengadakan survei adalah Badan Pengawasan MA bekerjasama dengan Pusat Studi Hukum dan Kebijakan (PSHK). Survei ini dimaksudkan untuk memantau sejauh mana pelaksanaan Surat Keputusan Ketua MA Nomor 026/KMA/SK/II/2012 tentang Standar Pelayanan Peradilan. Survei difokuskan pada kepuasan pengguna layanan pengadilan. Jenis layanan yang disurvei adalah administrasi pengadilan, bantuan hukum, layanan informasi dan layanan sidang tilang. Survei dilakukan terhadap 1.585 responden di sejumlah Pengadilan Agama (PA), Pengadilan Negeri (PN) dan Pengadilan Tata Usaha Negara (PTUN) di empat wilayah pengawasan. Wilayah I adalah Pulau Sumatera. Wilayah II adalah Pulau Jawa dan Bali. Wilayah III adalah Pulau Kalimantan dan Sulawesi. Dan, wilayah IV adalah Pulau Ambon, Papua, Nusa Tenggara Barat dan Nusa Tenggara Timur.

Pada dasarnya, ada dua jenis kepuasan masyarakat sebagai pengguna pengadilan: kepuasan terhadap pelayanan dan kepuasan terhadap putusan. Pertama, terkait dengan keadilan prosedural. Kedua, terkait dengan keadilan substantif. Hingga kini, sudah banyak survei yang mengukur kepuasan masyarakat terhadap layanan yang diberikan oleh pengadilan-pengadilan di lingkungan peradilan agama. Sebaliknya, belum ada survei yang secara spesifik berusaha mengukur kepuasan masyarakat pencari keadilan terhadap putusan yang dihasilkan pengadilan-pengadilan di lingkungan peradilan agama, khususnya pengadilan agama/mahkamah syar'iyah.

Setelah dilakukan survei, disimpulkan bahwa kinerja pengadilan-pengadilan di lingkungan peradilan agama pada umumnya baik pada hampir semua jenis layanan. Sebaliknya, pada aspek ketidakpuasan, rata-rata responden menunjukkan angka ketidakpuasan yang rendah. Meski demikian, bukan berarti kepuasan terhadap putusan itu tidak bisa diukur. Salah satu yang bisa dijadikan tolok ukur ialah jumlah putusan pengadilan agama/mahkamah syar'iyah yang diajukan banding.

Harus dipahami bahwa adil tidaknya suatu putusan bersifat subjektif. Adil menurut penggugat belum tentu adil di mata tergugat. Demikian juga sebaliknya. Putusan pengadilan yang tidak diajukan upaya banding menunjukkan bahwa isi putusan tersebut dianggap adil dan karena itu diterima dengan lapang dada oleh kedua pihak yang bersengketa. Pada tahun 2013, misalnya, 359 pengadilan agama/mahkamah syar'iyah menangani 511.019 perkara, sementara 29 pengadilan tinggi agama/Mahkamah Syar'iyah Aceh hanya menangani 2.242 perkara. Artinya, jika 
dikomparasikan, jumlah perkara di tingkat banding tidak sampai 0,5 persen dari jumlah perkara di tingkat pertama. Perkara dari peradilan agama yang diajukan kasasi dan peninjauan kembali ke MA lebih kecil lagi jumlah dan prosentasenya.

Merupakan hal yang sudah jelas, data itu menunjukkan bahwa sangat sedikit pencari keadilan yang tidak puas dengan putusan yang dihasilkan oleh pengadilan-pengadilan di lingkungan peradilan agama. "Kalau ada orang bilang, pelayanan peradilan agama dan kepuasan masyarakat terhadap peradilan agama rendah, itu hanya asumsi. Faktanya, pelayanan peradilan agama bagus dan masyarakat puas terhadap kinerja peradilan agama, kata Dirjen Badilag Purwosusilo Pernyataan Dirjen Badilag itu seakanakan sekaligus menangkis tesis Dory Reiling soal tiga keluhan utama pengguna pengadilan di seantero dunia. Ya, faktanya, penyelesaian perkara di peradilan agama tidak berlarut-larut, tidak sulit diakses, dan tentu saja tidak korup.

\section{c. Perkembangan Program Sistem Informasi Teknologi}

Perencanaan matang atas program kerja untuk meraih kondisi yang lebih baik di masa depan, merupakan langkah penting dalam sebuah lembaga peradilan. Peradilan Agama sebagai lembaga pelayanan publik, maka program unggulannya harus dapat diukur dan dirasakan langsung manfaatnya oleh masyarakat pencari keadilan. Perencanaan program dan dukungan keuangan terhadap peradilan agama harus berorientasi nasional dan internasional, tujuannya adalah agar harapan, akses masyarakat pencari keadilan terhadap peradilan agama, serta tingkat kepercayaan masyarakat baik nasional maupun internasional semakin kuat.

Sebelum Ketua Mahkamah Agung RI menyerukan "Sebelum ayam berkokok di pagi hari tanggal 1 Januari 2014, seluruh empat lingkungan peradilan di bawah Mahkamah Agung RI dalam melayani masyarakat pencari keadilan, harus sudah menggunakan Teknologi Informasi (IT)" yang disampaikan di forum Rakernas Mahkamah Agung di Manado tahun 2012, jauh sebelum itu, pada tahun 2005-2009, Direktorat Jendral Peradilan Agama telah mengembangkan Sistem Administrasi Perkara Peradilan Agama (SIADPA) di
Satker seluruh Pengadilan Agama secara bertahap, sehingga pda tahun 2008, 75\% Satker Pengadilan Agama telah menggunakan Sistem Informasi SIADPA tesebut.

Perkembangan dan kemajuan teknologi informasi yang demikian pesat telah menyebabkan perubahan kegiatan kehidupan manusia dalam berbagai bidang yang berpengaruh pada tuntutan kecepatan pelayanan peradilan agama. Kehadiran teknologi informasi dalam memberikan solusi efektifitas dan efesiensi aktivitas pelayanan menjadi alasan Dirjen Badan Peradilan Agama menempuh kebijakan pemanfaatan teknologi informasi di lingkungan Peradilan Agama. Dasar hukum yang dipakai dalam SK Ketua Mahkamah Agung RI Nomor 144/KMA/SK/VIII/2007 tanggal 28 Agustus 2007 tentang Pedoman Pelayanan Keterbukaan Informasi di Pengadilan. Atas dasar SK Ketua Mahkamah Agung tersebut, Dirjen Badan Peradilan Agama mengembangkan dua system berbasis teknologi informasi, yaitu: Sistem Informasi Administrasi Perkara Peradilan Agama (SIADPA), Sistem Informasi Manajemen Kepegawaian (SIMPEG). Kedua sistem tersebut mampu melipatgandakan kecepatan dan ketepatan serta kepuasan pelayanan kepada publik, dan internal kepegawaian melaui SIADPA dan SIMPEG. Sebagai contoh, pelayanan kenaikan pangkat pegawai pengadilan agama di seluruh Indonesia dapat memotong 14 langkah birokrasi yang di era manual harus dilewati. Data SMPEG dan Dokumen Elektronik (E-DOC) di pusat data Direktur Pembinaan Tenaga Teknis Peradilan Agama, pelayanan kenaikan pangkat bias dilayani hanya dalam tempo satu atau dua bulan saja, yang sebelumnya memakan waktu berbulan-bulan lamanya.

\section{d. Kerjasama Pengembangan SDM tenaga Teknis Peradilan Agama}

Pada awal penyatuan satu atap, selain Ketua Mahkamah Agung yang dekat dengan Pengadilan Agama, berbagai sumber daya manusia dari Pengadilan Agama juga mengisi posisi penting dan strategis di Mahkamah Agung, mulai dari Wakil Ketua Mahkamah Agung, Sekretaris Mahkamah Agung, Kepala Biro, dan beberapa jabatan penting lainnya. Saat itu juga dicanangkan pentingnya melanjutkan pendidikan 
akademik yang lebih tinggi bagi warga peradilan agama, baik pada tingkat S2 maupun tingkat S3. Kepercayaan masyarakat pencari keadilan terhadap lembaga peradilan tidak dapat dipungkiri memiliki keterkaitan dengan tingkat pendidikan hakim dan panitera. Dalam kasus tertentu, hakim yang berpendidikan rendah ternyata merasa minder dalam mengadili perkara yang pihak-pihak atau salah satu pihak berpendidikan tinggi. Fenomena tersebut mendorong Mahkamah Agung untuk membangun Memorial of understanding (MOU) dengan berbagai perguruan tinggi menjalin kerjasama membangun SDM hakim dan pegawai Mahkamah Agung di bidang gelaran pendidikan S1, S2, dan S3 baik bidang hukum, manajemen, akuntansi dan bidang lain yang dibutuhkan peradilan.

Oleh karena itu, Mahkamah Agung telah menjalin kerjasama dengan beberapa perguruan tinggi di dalam maupun di luar negeri. Kerjasama di dalam negeri, antara lain dijalin dengan UGM di Yogyakarta untuk bidang filsafat hukum, UI Jakarta, UMI Makassar, UMJ Jakarta, UIN Syarif Hidayatullah, USU Medan, UNS Solo, dan lain-lain. Dengan luar negeri dijalin kerjasama dengan Universitas Islam Sudan, Markfield Institute of Higher Education (MIHE) London Inggris, Al-Azhar Mesir dan lain-lain.

Pada tanggal 22 Juni 2009, Dirjen Badilag membuka kesempatan kepada pegawai pengadilan agama, baik hakim maupun non-hakim yang memiliki kemampuan bahasa Inggris dan bahasa Arab bergabung ke Dirjen Badilag dengan diseleksi terlebih dahulu. Mereka yang dinyatakan lulus ditempatkan pada ruang kelompok tenaga fungsional yang diberi tugas antara lain mengembangkan bahasa Inggris dan Arab malalui kegiatan pembinaan website Badilag-net kepada dunia Internasional.

Menyadari pentingnya peranan bahasa Inggris dan Arab bagi pengembangan lembaga dan hokum yang menjadi kewenangan peradilan agama, maka Mahkamah Agung menempuh kebijakan dalam perekrutan calon hakim peradilan agama mengutamakan sarjana yang menguasai bahasa arab dan juga bahasa inggris, baik lulusan dari dalam maupun luar negeri. Mahkamah Agung menerima lulusan Mesir yang bergelar LC untuk menjadi hakim di lingkungan peradilan agama. Para mahasiswa Fakultas Hukum Umum yang menguasai Islam, terutama yang menggali ilmu tambahan dari pondok pesantren dan mahir membaca dan memahami kitab kuning sangat berpeluang untuk merebut kursi hakim di lingkungan peradilan agama. Karena salah satu materi ujian seleksi penerimaan calon hakim peradilan agama, ada membaca dan memahami kitab kuning.

Bahasa Inggris dipandang penting dan harus dikuasai oleh hakim peradilan agama, karena perkara yang masuk di Pengadilan Agama Jakarta Pusat, diantaranya diajukan oleh pihak-pihak atau salah satu pihak berkewarganegaraan asing, atau dua-duanya bertempat tinggal di luar negeri. Selain itu, perkawinan campuran juga telah menjadi fakta fenomena menarik di tengahtengah kehidupan ummat Islam di kota-kota besar di Indonesia yang permasalahan hokum keluarga yang timbul harus diselesaikan di pengadilan agama.

\section{e. Apresiasi Luar Negeri terhadap Peradilan Agama}

Kebijakan Dirjen Badan Peradilan Agama menggunakan akses Informasi Teknologi sebagai alat sarana pelayanan masyarakat pencari keadilan dalam keterbukaan pengelolaan perkara melalui SIADPA dan pelayanan SDM peradilan melalui SIMPEG, sehingga menciptakan kesan pelayanan peradilan agama yang modern dengan pelayanan yang simpatik dan mengesankan, maka di mata internasional-peradilan agama-mendapatkan apresiasi tinggi.

\section{KESIMPULAN}

Berdasarkan uraian di atas, dapat disimpulkan bahwa eksistensi pengadilan agama pasca penyatuan satu atap menjadi lebih baik dan dinamis, baik dari segi indenpendensi maupun dari segi perkembangannya. Dari segi indenpensi, didukung karena komitmen Mahkamah Agung dalam menjaga indenpendensi lembaga peradilan. Sejak masih berada di bawah Kementerian Agama hingga kemudian hijrah ke Mahkamah Agung, peradilan agama jadi semacam anomali terhadap fenomena black justice market atau judicial corruption. Berbagai riset membuktikan hal itu. Sedangkan dari segi perkembangannya, pengadilan agama mengalami kemajuan pesat terutama dalam hal pembangunan infrastruktur, pelayanan publik, penguasaan dan penerapan informasi teknologi, 
pembangunan sumber daya manusia, dan apresiasi dunia internasional.

\section{SARAN}

Berdasarkan simpulan tersebut, sudah selayaknya pengadilan agama selalu menjaga indenpendensinya. Tidak dapat dipungkiri bahwa indenpendensi merupakan hal penting yang mesti dimiliki oleh lembaga peradilan sehingga menjadi badan peradilan yang berwibawa dan dipercaya. Sejalan dengan hal tersebut, pengadilan agama harusnya selalu meningkatkan kemampuan sumber daya manusia (SDM) aparat peradilan sehingga dapat membangun kepercayaan publik dan pencari keadilan.

\section{REFERENSI}

Abdullah, A. G. (2008). Paradigma Baru Peradilan Agama dalam Era Bagir Manan, dalam Bagir Manan Ilmuwan \& Penegak Hukum (Kenangan sebuah pengabdian). Mahkamah Agung.

Ahmad, Z. A. (2001). Membangun Negara Islam. Pustaka Iqra'.

Amin, S. H. (1985). Islamic Law in the Contemporary World. Royston Limitted.

An-Na'im, A. A. (1994). Dekonstruksi Syari"ah: Wacana Kebebasan Sipil, Hak Asasi Manusia dan Hubungan Internasional dalam Islam. LKIS.

Arto, M. (2003). Praktek Perkara Perdata pada Pengadilan Agama. Pustaka Pelajar.

Halim, A. (2000). Peradilan Agama dalam Politik Hukum di Indonesia. RajaGrafindo Persada.

Harjono, A. (1968). Hukum Islam, Kekuasaan dan Keadilannya, Bulan Bintang. Bulan Bintang.

Hasan, S., \& Sumitro, W. (1994). Dasar-dasar Memahami Hukum Islam Di Indonesia. Usaha Nasional.

Ibrahim, J. (2010). Teori \& Metodologi Penetitian Hukum Normatif. Bayumedia Publishing.

Ka'bah, R. (2002). Penegakan Hukum Di Indonesia. Jurnal Pusdiklat Mahkamah Agung RI, 1(1), 38.

Mertokusumo, S. (2004). Penemuan Hukum. Liberty.
Mujahidin, A. (2008). Pembaharuan Hukum Acara Perdata; Peradilan Agama dan Mahkamah Syr'iyah di Indonesia. IKAHI.

Rasyid, R. A. (2000). Hukum Acara Peradilan Agama. Raja Grafindo Persada. 